\title{
Psychological and Pedagogical Assistance to Students During the Coronavirus Pandemic
}

\author{
Mazurchuk N.I. Mazurchuk E.O.
}

\author{
Ural State Pedagogical University, Yekaterinburg, Russian Federation \\ *Corresponding author.Email: Mazurchuk-nina@rambler.ru
}

\begin{abstract}
The article highlights the main reasons that actualize the need to organize remote psychological and pedagogical assistance to students during the coronavirus pandemic. Among them, the authors consider those ones that lead to changes in the lifestyle of all segments of the population, and those that negatively affect students. Within the study of the problem raised, theoretical and empirical methods were used to identify the theoretical foundations and develop the main provisions of the program for remote psychological and pedagogical assistance to students "Effective functioning in conditions of lockdown". The article presents a most suitable option for organizing remote psychological and pedagogical assistance to students in offline and online formats using various means of communication, services and programs for video conferences. The research materials are of practical value for specialists who provide psychological and pedagogical assistance
\end{abstract} to students in a remote format.

Keywords: coronavirus pandemic, remote format, psychological and pedagogical assistance

\section{INTRODUCTION}

1.1. The world today is facing a rapid spread of the coronavirus pandemic. This global challenge has dramatically changed the way of life of all segments of the population due to the emergence of a number of atypical risks:

- reduced financial well-being;

- infections;

- loss of social contacts and personal freedom.

The identified risks, according to the experts (Dorokhov, 2020, Konyukhovskaya, 2020, Mitina, 2020, Pervichko, 2020, Stepanova, 2020), are the main cause of disadaptation in a pandemic. Students have the least resources to resist risks and retain the necessary level of adaptability. This is due to a number of reasons. First, in their social development situation, coevals take a leading position, and the lack of interaction with them negatively affects the psychological health of students. Second, mental processes in this segment of the population are at the stage of formation, so they remain the most susceptible to various negative impacts. Third, they have no experience of functioning in dynamically changing conditions, including in conditions of restrictions. In this regard, the need for the organization of psychological and pedagogical assistance to students is updated, taking into account the restrictions imposed - transition to a distance (remote) learning format.

1.2. During the pandemic psychological and pedagogical assistance to students is not possible in direct interaction, so it is carried out remotely - using remote educational technologies. Today, two formats of such interaction are most widely used: offline and online. Offline interaction in the process of psychological and pedagogical assistance is carried out in a deferred mode - doing homework and following recommendations received by students at online meetings (Gavrilova, 2003, Choshanov, 2011, Grebenyuk, 2015, Bulan, 2015, Solovyov, 2015). Online interaction involves organization of psychological and pedagogical assistance in real time using various means of communication, services and programs for video conferences.

1.3. Psychological and pedagogical assistance to students in a remote format is now considered by the scientific community as a special type of psychological assistance. The authors claim that it is aimed at supporting the child's naturally developing processes and reactions. Psychological and pedagogical assistance is aimed at opening up prospects for personal growth of students and the possibility of their transition to self-help. The result of psychological and pedagogical assistance to students will be a formed integrative quality of personality - adaptability - the ability of a child to achieve balance in relationships with others and the world around them, both in favorable and in extreme conditions (Osukhova, 2001, Ovcharova, 2003, Shipitsina, 2003, Fedorova, 2003, Mukhina, 2011, Mazorchuk, 2016).

\section{METHODS OF RESEARCH}

2.1. The methodological basis of the research is based on the fundamental principles of the system (Ananyev, 2001, Asmolov, 2009) and subject-activity approaches (Rubinshtein, 1986, Abulkhanova-Slavskaya, 2001, Brushlinskiy, 2003); theoretical and empirical 
achievements in research of psychological and pedagogical assistance (Rogers, 1959, Dubrovina, 2001, Ovcharova, 2003, Fedorova, 2003).

2.2. The purpose of this article is to identify the theoretical foundations of psychological and pedagogical assistance and to present a program of remote psychological and pedagogical support for students during the coronavirus pandemic

2.3. A set of interrelated and mutually complementary methods was used to achieve this goal and to verify the initial provisions: theoretical (problem analysis of primary sources, generalization, systematization); empirical: design (development of a program of psychological and pedagogical assistance to students "Effective functioning in conditions of lockdown").

\section{RESULTS OF THE STUDY}

Taking into account the identified theoretical foundations, a program of remote psychological and pedagogical assistance to students "Effective functioning in conditions of lockdown" was developed, which includes a number of components.

3.1. The goal: to develop skills for effective functioning in conditions of the coronavirus pandemic.

3.2. Tasks:

1) to form ideas about the mechanisms of attracting and retaining the audience's attention in remote communication;

2) to give a positive experience of using mechanisms to attract and retain the audience's attention in remote communication;

3) to give a positive experience of self-presentation in remote communication;

4) to understand the importance of effective communication and business communication skills in a remote format;

5) to develop effective communication and business communication skills in a remote format;

6) to promote the development of communication for solving problems of interpersonal and intercultural interaction in a remote format;
7) to contribute to the development of the ability to work in a team within remote communication

8) to promote the development of the ability to tolerate social, ethnic, religious and cultural differences in remote communication;

9) to understand the importance of goal-setting and goalsetting skills in remote communication;

10) to give a positive experience of using goal-setting and goal-setting skills in remote communication;

11) to form ideas about the mechanisms of formation of goal-setting and goal-setting skills in remote communication;

12) to give a positive experience of using mechanisms for forming goal-setting and goal-setting skills within remote communication.

3.3. Group composition: a group can consist of 15 people aged 14 to 17 . This group, on the one hand, already carries the results of the influence of various factors, and on the other - its representatives remain quite flexible, subject to various influences.

3.4. Architecture of the program. The program consists of 4 blocks. The first block "Mechanisms for attracting and retaining the audience's attention in remote communication" is aimed at forming ideas about the mechanisms for attracting and retaining the audience's attention, obtaining positive experience in using mechanisms for attracting and retaining the audience's attention and self-presentation.

The second block "Effective communication and business communication in a remote format" is aimed at developing the skills of effective communication and business communication.

The third block "Team building and communication in a group within remote communication" is aimed at updating the ability to communicate to solve problems of interpersonal and intercultural interaction and work in a team, tolerant perception of social, ethnic, religious and cultural differences.

The fourth block "Goal formation and goal setting in remote communication" is aimed at developing students' goal-formation and goal-setting skills.

3.4.1. Calendar and thematic plan.

Table 1 Calendar and thematic plan of distance meetings

\begin{tabular}{|c|c|c|c|}
\hline Date & Title of block & Implemented tasks & Effective practices \\
\hline & Block 0. Preparatory & $\begin{array}{l}\text { Does not solve the main tasks of the program. } \\
\text { It is aimed at emotional "warming up", in- } \\
\text { depth acquaintance and entry of students into } \\
\text { the group. }\end{array}$ & $\begin{array}{l}\text { "Set of rules"; "Three questions"; } \\
\text { "Hello, everyone". }\end{array}$ \\
\hline & $\begin{array}{l}\text { Block 1. Mechanisms for } \\
\text { attracting and retaining the } \\
\text { audience's attention in } \\
\text { remote communication }\end{array}$ & $\begin{array}{l}\text { 1) to form ideas about the mechanisms of } \\
\text { attracting and retaining the audience's } \\
\text { attention in remote communication; } \\
\text { 2) to give a positive experience of using } \\
\text { mechanisms to attract and retain the } \\
\text { audience's attention in remote } \\
\text { communication; } \\
\text { 3) to give a positive experience of self- } \\
\text { presentation in remote communication; }\end{array}$ & $\begin{array}{l}\text { mini-lecture "Public speaking"; } \\
\text { mini-lecture "Signs of public } \\
\text { speaking"; } \\
\text { "Self-presentation"; } \\
\text { mini-lecture "Excitement and I"; } \\
\text { "I'm calm". }\end{array}$ \\
\hline & Block 2. & 4) to understand the importance of & mini-lecture "Answers to questions \\
\hline
\end{tabular}




\begin{tabular}{|c|c|c|}
\hline $\begin{array}{l}\text { Effective communication and } \\
\text { business communication in a } \\
\text { remote format }\end{array}$ & $\begin{array}{l}\text { effective communication and business } \\
\text { communication skills in a remote format; } \\
\text { 5) to develop effective communication and } \\
\text { business communication skills in a remote } \\
\text { format; }\end{array}$ & $\begin{array}{l}\text { in public speeches"; } \\
\text { "Ask me"; } \\
\text { "I would like to say"; } \\
\text { "Debates". }\end{array}$ \\
\hline $\begin{array}{l}\text { Block 3. Team building and } \\
\text { communication in the group } \\
\text { in remote communication }\end{array}$ & $\begin{array}{l}\text { 6) to promote the development of } \\
\text { communication for solving problems of } \\
\text { interpersonal and intercultural interaction in a } \\
\text { remote format; } \\
\text { 7) to promote the development of the } \\
\text { ability to work in a team in remote } \\
\text { communication; } \\
\text { 8) to promote the development of the } \\
\text { ability to tolerate social, ethnic, religious and } \\
\text { cultural differences within remote } \\
\text { communication; }\end{array}$ & $\begin{array}{l}\text { "Team goals"; } \\
\text { "I look like..."; } \\
\text { "Group collage"; } \\
\text { "Our crest»; } \\
\text { "No one knows that I...". }\end{array}$ \\
\hline $\begin{array}{l}\text { Block } 4 \text {. Goal formation and } \\
\text { goal setting in remote } \\
\text { communication }\end{array}$ & $\begin{array}{l}\text { 9) to understand the importance of goal- } \\
\text { setting and goal-setting skills in remote } \\
\text { communication; } \\
\text { 10) to give a positive experience of using } \\
\text { goal-setting and goal-setting skills in remote } \\
\text { communication; } \\
\text { 11) to form ideas about the mechanisms of } \\
\text { formation of goal-setting and goal-setting } \\
\text { skills in remote communication; } \\
\text { 12) to give a positive experience of using } \\
\text { mechanisms for forming goal-setting and } \\
\text { goal-setting skills in remote communication }\end{array}$ & $\begin{array}{l}\text { mini-lecture "Goal - goal setting - } \\
\text { goal formation"; } \\
\text { "SMART - pit"; } \\
\text { "Splitting goals". }\end{array}$ \\
\hline
\end{tabular}

3.5. The duration of meetings is 1 hour per week using various means of communication, services and programs for video conferences, depending on the technical capabilities of students and the educational organization. The total duration is 27 weeks.

3.6. The program is based on the principles of gradualism: each subsequent stage should follow logically from the previous one. As well as on the principles of taking individual characteristics, reflection and identification into account. As a result, students gradually get deeper into the learning process, which is the basis for productive interaction and the formation of their skills of effective functioning in the context of the coronavirus pandemic.

3.7. Planned results. Students:

- have an understanding of the mechanisms of attracting and retaining the audience's attention during remote communication;

- use mechanisms to attract and retain the audience's attention during remote communication;

- understand the importance of effective communication and business communication skills in a remote format;

- have experience of self-presentation in remote communication;

- have the skills of effective communication and business communication in a remote format;

- are capable of communication to solve problems of interpersonal and intercultural interaction in a remote format;

- are able to work in a team during remote communication;

- are able to tolerate social, ethnic, religious and cultural differences during remote communication;
- understand the importance of goal-setting and goalsetting skills within remote communication;

- have a positive experience of using goal-setting and goalsetting skills within remote communication;

- have an understanding of the mechanisms for developing goal-setting and goal-setting skills within remote communication;

- have positive experience in using mechanisms for developing goal-setting and goal-setting skills during remote communication.

3.8. Forms and methods of work. When implementing the program, group remote online forms of work are carried out using various means of communication, services and programs for video conferences:

- distance mini-lectures;

- discussions;

- brainstorming;

- video chat;

- video business cards (self-presentations);

- panel discussion;presentations of mini-projects on goal setting, etc.

Renmote individual offline forms of work:

- homework based on the results of mini-lectures.

3.9. Evaluation of the impact. Evaluation of the program's performance is carried out through:

- collecting feedback from group members;

- the use of reflective techniques: "Suitcase", "Palm",

"Hippie's t-shirt" morning and evening share and others;

- diagnosis of students using techniques: diagnosis communication and organizational skills (COS) by V. V. Sinyavskiy, V. A. Fedorishina, diagnostics of development 
of goal forming and goal setting of students by A. G. Asmolov, the coach's expert assessment.

\section{DISCUSSION OF THE RESULTS}

Comparing the existing programs of psychological and pedagogical assistance used in domestic and foreign practice, we can summarize that this process has a qualitative variety of types, directions and forms that differ in their orientation, subject and object. At the same time, remote psychological and pedagogical assistance to students during the coronavirus pandemic (Dorokhov, 2020, Konyukhovskaya, 2020, Mitina, 2020, Pervichko, 2020, Stepanova, 2020) is of particular relevance according to recent research. However, with all the variety of approaches to the consideration of psychological and pedagogical assistance to students, there is little knowledge of the methodological foundations of its application during the coronavirus pandemic. Despite the lack of a unified methodological approach, our analysis of primary sources suggests that psychological and pedagogical assistance to students during the coronavirus pandemic should be aimed at:

- creating conditions for them to understand and accept their own position during remote communication;

- formation of value-semantic bases of remote communication;

- actualization of personal responsibility within remote communication.

\section{CONCLUSION}

It is established that the developed program of remote psychological and pedagogical assistance to students during the coronavirus pandemic "Effective functioning in conditions of lockdown" makes it possible to organize interaction with students in online and offline formats. It is aimed at developing communication skills, goal setting and self-presentation in a remote format. The program contributes to the formation of experience in using the skills acquired in the process of psychological and pedagogical assistance.

The materials of the article can be useful in practical terms for specialists and managers of educational organizations that carry out their activities in a remote format; in the practical activities of educational psychologists, centers for psychological assistance to families and children.

Taking into account the results of the research, we can identify a number of activities that require further study and improvement: deepening and expanding the content of the program blocks described in the article; developing scientific and methodological support for the process of remote psychological and pedagogical assistance to students in order to popularize it.

\section{REFERENCES}

[1] K. A. Abulkhanova-Slavskaya, T. N. Berezina (2001), Time of personality and time of, Saint Petersburg, Russia, 299 p.

[2] B. G. Ananyev (2001) Man as a subject of knowledge, Saint Petersburg, Russia, 288 p.

[3] A. G. Asmolov (2009), "System-activity approach in the development of new generation standards", Pedagogika, No. 4, pp. 18-22.

[4] A.V. Brushlinskiy (2003) "Psychology of the subject", Moscow, Russia; Saint Petersburg, Russia, 272 p. (in Russian).

[5] I. V. Dubrovina (2001) "Family and child Socialization", Vozrastnaya i pedagogicheskaya psihologiya, Moscow, Russia, pp. 50-54.

[6] E. O. Mazurchuk, N. I. Mazurchuk (2016)

"Psychological and pedagogical assistance to the family: theoretical understanding and practice of implementation", Pedagogicheskoye obrazovaniye v Rossii, No. 3, pp. 132-138.

[7] R. V. Ovcharova (2003) Psychological assistance to parenthood, Moscow, Russia, 319 p.

[8] N. G. Osukhova (2001) "Psychological assistance to families and to an individual in a crisis situation", Shkolniy psiholog, No. 31.

[9] E. I. Pervichko, O. V. Mitina, O. B. Stepanova, Ju. E. Konyukhovskaya, E. A. Dorokhov (2020)

"Perception of COVID-19 by the population of Russia in the conditions of the pandemic 2020", Klinicheskaya i spetsialnaya psihologiya, Vol. 9, No. 2.

[10] S. L. Rubinshtein (1986) Fundamentals of general pedagogy, Vol.1, Moscow, Russia.

[11] Yu. P. Fedorova (2003) Psychological assistance in personal development of primary school children in private schools: Author's thesis, Kursk, Russia, 18 p.

[12] N. V. Abramovskikh, V. V. Tolmacheva, N. N. Vasyagina, N. I. Shempeieva (2019) "Research and methodological assistance to professional activity quality of a lecturer", The European Proceedings of Social \& Behavioural Sciences EpSBS, pp. 10-17.

[13] E.O. Mazurchuk, N.I. Mazurchuk (2020) "Effective Practices of Psychological and Pedagogical Assistance for Deviant Mothers in the Digital Educational Environment", Series: Advances in Social Science, Education and Humanities Research Proceedings of the International Scientific Conference "Digitalization of Education: History, Trends and Prospects" (DETP 2020), pp.158-162.

[14] C. R. Rodgers (1959) "A theory of therapy, personality and interpersonal relationships, as developed in the client-centered framework", Psychology: A study of a science, ed. by S. Koch, New York : McGraw-Hill, № 3, pp. 183-256. 